\title{
Visualization Study of Terrorist Activities in Asia Based on UCINET
}

\author{
Qiwu Wu*, Lingzhi Jiang and Mingzhu Zheng \\ Engineering University of CAPF, Xi'an, 710086, China \\ *Corresponding author. Email: wuqiwu700@163.com
}

\begin{abstract}
After 9.11, terrorism has become the hotspot of research by scholars all over the world, and the fight against terrorism has been intensified. However, under the fight of the whole society, the phenomenon of "the more we fight against terrorism, the more active it becomes" has appeared, which is especially serious in Asia. In this context, we collected data on terrorist activities in Asia by using the GTD anti-terrorist database, and analyzed the singularity of the network of "time-region" and "target type-attack type" relations of terrorist activities by using social network analysis and UCINET. It can be deduced that the Asian region is characterized by the criminalization of terrorist activities, the expansion of the geographical area of activities, the diversification of attack methods and the complexity of the types of targets. Finally, corresponding counter-terrorism strategies will be formulated on the basis of the conclusions, which will provide a guiding theory for future counter-terrorism efforts.
\end{abstract}

Keywords: UCINET, Asia, Terrorism, Counter-terrorism strategy.

\section{INTRODUCTION}

In the 21 st century, under the background of globalization, the global and transnational nature of terrorism has become more and more prominent [1], which has become a thorny issue plaguing the whole international community, and counter-terrorism has become a proposition of the times that all mankind must face together. In addition, with the rapid advancement of the information technology revolution in the world and the increasing complexity of computer network structure and equipment, terrorism is becoming networked in terms of organization, theory, strategy and information technology [2]. Terrorist organizations will realize the transformation from the traditional vertical hierarchical organization form to the network organization form in the digital era, so it becomes the trend to study and analyze terrorism from the network perspective. Therefore, based on the social network analysis method, this paper collects relevant information about terrorist activities through GTD anti-terrorism database, and then analyzes the singular value of the matrix data by using UCINET, so as to obtain the characteristics of terrorist activities and propose corresponding anti-terrorism strategies in the end.

\section{RESEARCH AND ANALYSIS OF TERRORIST NETWORKS IN THE ASIAN REGION}

\subsection{Research Methodology and Data Sources}

Social network analysis is a quantitative analysis of relational networks based on mathematical and graphical methods. The first application of this method in the study of criminal networks was by Sparrow [3], but its widespread use in the field of counter-terrorism occurred after the events of September 11. Valdis Krebs [4], for example, has used the method to model the structural networks of terrorists and has produced useful results, which also provide good ideas for the study of terrorism.

The main source of data for this article is the Global Terrorism Database (GTD). It has compiled statistics on terrorist attacks in the world from 1970 to 2019 , with a very large volume of data on terrorist attacks, now including more than 200,000 cases. Since 9.11 is regarded as an important sign that international terrorism has entered a new stage of development, this database mainly collects data on the time, location, target type and attack type of terrorist activities in Asia after 9.11 for analysis. 


\subsection{Building a Matrix of Terrorist Relationships}

\author{
$\begin{array}{llllllllllllllllll}1 & 2 & 3 & 4 & 5 & 6 & 7 & 8 & 9 & 10 & 11 & 12 & 13 & 14 & 15 & 16 & 17 & 18\end{array}$ \\ 2001200220032004200520062007200820092010201120012201320142015201620172018
}

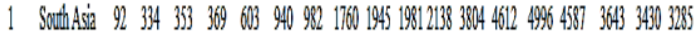

2 EastAsia $12 \begin{array}{llllllllllllllllllllll}2 & 6 & 4 & 2 & 1 & 0 & 25 & 7 & 1 & 4 & 4 & 15 & 43 & 28 & 8 & 7 & 6\end{array}$ 3SoutrasatAsia $45110 \quad 1459520422236551456147335658811881002107310771021874$

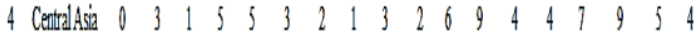

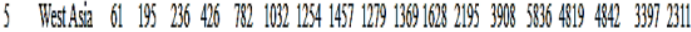

Figure 1 Time-area matrix data

\begin{tabular}{|c|c|c|c|c|c|c|c|c|c|c|}
\hline & & $\begin{array}{c}1 \\
\text { Amed } \\
\text { attacks }\end{array}$ & $\begin{array}{c}2 \\
\text { Assassi } \\
\text {-nations }\end{array}$ & $\begin{array}{c}3 \\
\text { Bombing' } \\
\text { explosions }\end{array}$ & $\begin{array}{c}4 \\
\text { Infrastructure } \\
\text { attacks }\end{array}$ & $\begin{array}{c}5 \\
\text { Hijacking }\end{array}$ & $\begin{array}{c}6 \\
\text { g Hostage-taling } \\
\text { (roadblock incident) }\end{array}$ & $\begin{array}{c}7 \\
\text { Hostage-taking } \\
\text { t) (bithapping) }\end{array}$ & $\begin{array}{c}8 \\
\text { Unamed } \\
\text { attack }\end{array}$ & $\begin{array}{c}9 \\
\text { Uninown }\end{array}$ \\
\hline & Govermment (general) & 2746 & 2859 & 3920 & 665 & 4 & 34 & 918 & 33 & 263 \\
\hline & Govenment (Eiplomatic) & 136 & 42 & 322 & 19 & 6 & 1 & 68 & 1 & 7 \\
\hline & Public equipmentif facilities & 87 & 3 & 1559 & 200 & 2 & 4 & 18 & 1 & 19 \\
\hline & rsons and property of citizens & 5761 & 1172 & 17354 & 860 & 45 & 50 & 2679 & 140 & 915 \\
\hline & Mifitary matters & 5052 & 396 & 728 & 233 & 12 & 21 & 541 & 50 & 1567 \\
\hline & Maritime & 11 & 0 & 45 & 6 & 15 & 1 & 21 & 1 & \\
\hline & Police & 5747 & 915 & 7181 & 352 & 11 & 43 & 669 & 55 & 1012 \\
\hline & NGO & 138 & 19 & 112 & 21 & 1 & 2 & 158 & 2 & 11 \\
\hline & Educational instututions & 479 & 49 & 1673 & 383 & 3 & 26 & 213 & 44 & \\
\hline & Business & 1122 & 33 & O & 1120 & 27 & 79 & 579 & 36 & \\
\hline & Transportation & 319 & 3 & 1985 & 258 & 29 & 12 & 59 & 13 & 25 \\
\hline & Joumalists and media & 207 & 236 & 213 & 57 & 2 & 7 & 237 & 20 & \\
\hline & Religious figures institutions & 547 & 166 & 1230 & 178 & 0 & 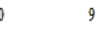 & 99 & 12 & \\
\hline & Comminications facility & 31 & 0 & 250 & 233 & 0 & 0 & 14 & 2 & \\
\hline & Terronistshnon-state militias & 755 & 287 & 1203 & 31 & 4 & 2 & 187 & 1 & 259 \\
\hline & Tourism industry & 20 & 0 & 52 & , & 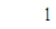 & 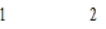 & 21 & 0 & 1 \\
\hline & Other & 80 & 2 & 4640 & 32 & 1 & 1 & 7 & 0 & \\
\hline
\end{tabular}

Figure 2 Attack type - target type matrix data

\subsection{Analysis of Terrorist Network Models in the Asian Region}

Singular value decomposition (SVD) is a method to find the factors behind 2-mode multivalued network data by reducing the number of dimensions of the relational data [5]. By examining the singular values and their factor loadings we can infer the characteristics of the events.

\subsubsection{SVD Analysis of the "Time-area" Network of Relationships}

SINGULAR VALUES

\begin{tabular}{|c|c|c|c|c|c|c|}
\hline FACTOR & VALUE & PERCENT & CUM \% & RATIO & PRE & CUM PRE \\
\hline 1: & 16411.27 & 87.0 & 87.0 & 8.468 & 0.979 & 0.97 \\
\hline 2: & 1938.10 & 10.3 & 97.2 & 4.034 & 0.020 & 0.99 \\
\hline 3: & 480.45 & 2.5 & 99.8 & 13.968 & 0.001 & 1.0 \\
\hline 4: & 34.40 & 0.2 & 100.0 & 3.817 & 0.000 & 1.00 \\
\hline 5: & 9.01 & 0.0 & 100.0 & 3.817 & 0.000 & 1.00 \\
\hline$======$ & $=====$ & $======$ & $=====$ & $====$ & & \\
\hline
\end{tabular}

Figure 3 "Time-area" matrix singularities

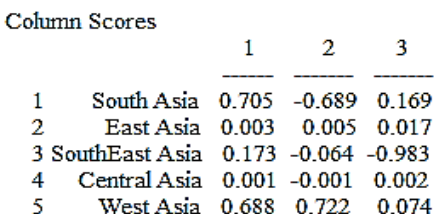

Figure 4 Area scale

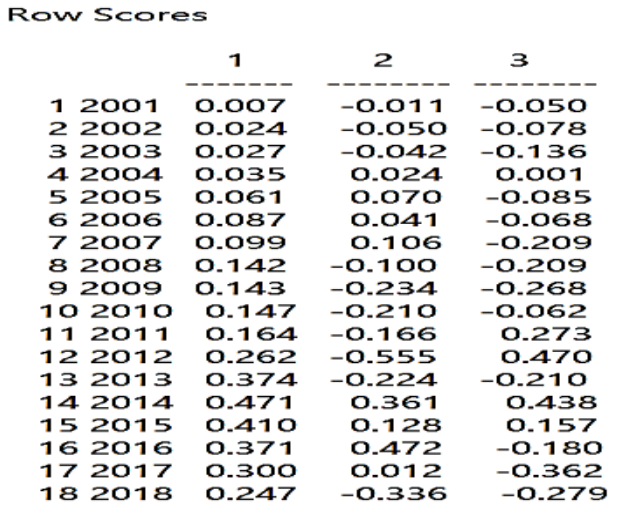

Figure 5 Time scale

As can be seen in Figure 3, the first singular value is 16411.27 , which is $87 \%$ of the total, indicating greater importance. And it can be seen from the area scale that it reflects the frequency of terrorist attacks. If we look at the time scale, we can see that terrorist activities became more and more active after 2001, and the phenomenon of " the more we fight against terrorism, the more active it becomes" appeared, it peaked in 14 years and then slightly decreased, but still maintained a high level. It means that terrorism is still a global problem that needs to focus on and solve in the future.

\subsubsection{SVD Analysis of "Attack Type-target Type" Relational Networks}

SINGULAR VALUES

\begin{tabular}{|c|c|c|c|c|c|c|}
\hline FACTOR & VALUE & PERCENT & CUM \% & RATIO & PRE & CUM PRE \\
\hline 1: & 24185.01 & 72.4 & 72.4 & 5.639 & 0.951 & 0.951 \\
\hline 2: & 428 & 12.8 & .3 & 1. & 0.034 & 985 \\
\hline 3: & 2510 & 7.5 & 92.8 & 2.469 & 0.012 & 0.996 \\
\hline 4: & 1017.00 & 3.0 & 95.8 & 1.180 & 0.002 & 0.998 \\
\hline 5: & 861.68 & 2.6 & 98.4 & 1.931 & 0.001 & 1.000 \\
\hline 6: & 446.29 & 1.3 & 99.8 & 13.205 & 0.000 & 1.000 \\
\hline 7: & 33.80 & 0.1 & 99.9 & 1.172 & 0.000 & 1.000 \\
\hline 8: & 28.83 & 0.1 & 100.0 & 1.861 & 0.000 & 1.000 \\
\hline 9: & 15.49 & 0.0 & 100.0 & 1.861 & 0.000 & 1.000 \\
\hline & $\begin{array}{r}===== \\
33387.76\end{array}$ & $\begin{array}{r}==== \\
100.0\end{array}$ & $====$ & $====$ & & \\
\hline
\end{tabular}

Figure 6 "Attack type - target type" singular value

Column Scores

\begin{tabular}{|c|c|c|c|c|}
\hline & & 1 & 2 & 3 \\
\hline & Armed attacks & 0.389 & -0.841 & 0.233 \\
\hline & Assassinations & 0.084 & -0.300 & -0.878 \\
\hline & Bombing/explosions & 0.905 & 0.396 & 0.009 \\
\hline & Bombing/explosions & 0.054 & 0.030 & -0.209 \\
\hline & Hijacking & 0.002 & 0.004 & -0.000 \\
\hline & ge-taking (roadblock incident) & 0.004 & -0.001 & -0.007 \\
\hline 7 & Hostage-taking (kidnapping) & 0.118 & 0.058 & -0.271 \\
\hline & Unarmed attack & 0.007 & 0.001 & -0.004 \\
\hline & & & 0.205 & \\
\hline
\end{tabular}

Figure 7 Attack type scale 


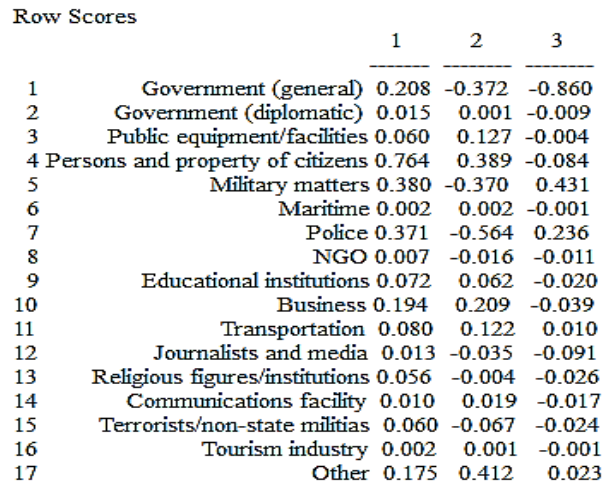

Figure 8 Target type scales

As can be seen from Figure 6, the first three singularity values are larger percentages of the total, indicating more criticality. And from Figures 7 and 8, it can be seen that the first one reflects the degree of destruction of a terrorist attack, the second one refers to the ease of a terrorist attack, and the third one is the extent of the impact of a terrorist attack. From these findings, it is possible to analyse the magnitude of the loadings of the different factors on the three singularities. For example, in figure 7, the loading for "destructiveness" of an armed attack is 0.389 and "simplicity" is -0.841. The "sphere of influence" load value of 0.233 . These indicate that it is more difficult for terrorists to carry out attacks through armed attacks, but that the damage and impact on society is greater in this way.

\section{CHARACTERISTICS OF TERRORIST ACTIVITIES IN THE ASIAN REGION}

First, the crime of terrorist activities has become more active. Before the twenty-first century, global crimes of terrorist activities also occurred from time to time, but their number, scale and impact were still limited to a certain range. In the 21 st century, however, the forms and scales of terrorist activities have changed in new ways. It can also be seen from the time scale that terrorist attacks increased rapidly after the September 11 incident, reaching a peak in 2014 and then declining somewhat, but still remaining at a relatively high level, indicating that terrorism has become one of the major non-traditional security threats that cannot be ignored by countries around the world.

Secondly, the geographical expansion of the activities of terrorist forces. From the regional scale, it can be seen that West Asia, South Asia and South-East Asia are the regions where terrorist activities are most frequent; and from the analysis of centrality, it is also found that the three centrality values for different regions are very close to each other, which indicating that terrorist forces are not limited to a certain region but have begun to spread on a global scale.
Third, the methods of terrorist attacks have been diversified and the types of targets complicated. In the attacks and sabotage carried out by terrorist organizations, different means are used to target different targets. From the attack type scale, we can see that the terrorist attack methods are mainly armed attacks and explosions/bombings. And by analyzing the singularity value, it can be found that it is related to the ease of carrying out attacks by terrorist organizations, the intensity of destruction and the strength of their impact on society. And from the social level, the more massive the bombing attack, the easier it is to get media coverage and attention, and the more likely it is to cause social panic, thus becoming the most popular means and methods of terrorists [6]. According to the target type scale, the target of terrorist attacks is more likely to be weak resistance, the number of victims and easy to cause widespread panic in public places and politically significant government departments and the military and other state apparatus, but the type of target is also increasingly complex and diverse.

\section{TACTICS IN THE FIGHT AGAINST TERRORISM}

We know that the traditional counter-terrorism concept has certain limitations in dealing with terrorism in the new situation. Therefore, it is necessary to deeply grasp the core issues in the counter-terrorism work and find an effective counter-terrorism strategy [1].

Firstly, we should improve the concept, thinking and way of rule of law in the field of counter-terrorism. The law has authority, continuity and stability, and plays an irreplaceable and important role in counter-terrorism work, and imperfections in the law and system may lead to an increase in terrorist attacks [7]. In view of the current characteristics of China's criminal legislation on counter-terrorism, which is "strict but not rigorous", the National Security Law and the Anti-Terrorism Law should be taken as the basis for implementing counter-terrorism policies and measures in accordance with the law, and promoting the change of the legislative structure to "strict but not rigorous" [8].

Second, strengthening the construction of counter-terrorism intelligence. In view of the characteristics of terrorist crimes that are sudden, covert and difficult to detect, to maximize the destruction of terrorist activities before the operation [1], we should improve the counter-terrorism intelligence system, improve the terrorist intelligence data mining technology, and establish a comprehensive information management system [9]. At the same time, it is necessary to establish a system of intelligence exchange and data sharing between different functional departments (armed police forces and public security organs) in order to complete the analysis and 
decision-making in the fight against terrorism in the shortest possible time.

Thirdly, a professional elite counter-terrorism force should be established. In the face of the new situation of terrorism, which is characterized by flexible and changing means and methods, it is necessary to study the theory of counter-terrorism suited to China's national conditions, improve the operational command system under different circumstances (mountain counter-terrorism, cyber counter-terrorism, overseas counter-terrorism and urban counter-terrorism, etc.) and set up a sharp force capable of carrying out a variety of counter-terrorism operational tasks.

Fourthly, international counter-terrorism law enforcement and judicial cooperation should be strengthened. The transnational nature of modern terrorist crimes is becoming more and more obvious, the world's well-known terrorist organizations almost have branches in many countries, and the cooperation among terrorist organizations is also becoming stronger and stronger. Therefore, we should not only do a good job in domestic counter-terrorism work, but also pay attention to international counter-terrorism cooperation, establish a "united international counter-terrorism front" with various countries [10], vigorously explore and expand the scope of counter-terrorism judicial cooperation with other countries, and strive to contribute to the cause of counter-terrorism.

\section{CONCLUSION}

This paper studies terrorist activities in Asia based on social network analysis, and analyzes the singular values of "time - area" and "attack type - target type" through UCINET, which draws out the characteristics of terrorist activities and proposes corresponding counter-terrorism strategies for the Assistance in the fight against terrorism.

\section{ACKNOWLEDGMENT}

This work is supported by the Natural Science Basic Research Plan in Shanxi Province of China (No.2020JM-361), the Young and middle-aged scientific research backbone projects of Engineering University of PAP (No.KYGG201905) and the basic research foundation project of Engineering University of PAP (No.WJY201920, No.WJY202019), military theory research project of Engineering University of
PAP (No.JLY2020085), education and teaching fund project of Engineering University of PAP (No.WJJ202039), the PAP's Military Scientific Research Mandatory Project (No.WJ2020A020047, No.WJ2020A020048, No.WJ2020A020049).

\section{REFERENCES}

[1] James M. Poland, translated by Wang Zhen. Understanding Terrorism: Terrorist Organizations, Terrorist Tactics and Their Responses, Shanghai: Shanghai Academy of Social Sciences Press, 2019.

[2] Tang Shuchen. Post-Xinguan era: the development and confrontation of cyberterrorism, Journal of Hebei Public Security Police Professional College, 2020, 20(03), 68-70.

[3] Liu Zhiwei. Counter-terrorism in Chinese Perspective and Extraterritorial Reference, Beijing: Chinese People's Public Security University Press, 2019.

[4] Krebs V E. Mapping Networks of Terrorist Cells, Connections, 2001, 24(3): 43-52.

[5] Liu Jun. Overall network analysis lecture: UCINET Software Practical Guide, Shanghai: Shanghai People's Publishing House, 2009.

[6] M.L.Commons, T.Q.Duong. Understanding terrorism: A behavioral developmental approach, 2019, 8:74-96.

[7] Umer Shahzad, Suleman Sarwar, Muhammad Umar Farooq, et al. USAID, official development assistance and counter terrorism efforts: Pre and post 9.11 analysis for South Asia,2019.

[8] Kunyi Jian, Peng Nai, Tao Yu, et al. The establishment of the Absichtsdelikte model of criminal law for controlling terrorist crimes: The case of China,2020, 60

[9] Bruce W. Dearstyne. Fighting terrorism, making war: Critical insights in the management of information and intelligence, 2005, 22(2):170-186.

[10] Wang Qi, Tian Yiming. GTD Data Analysis of Global Terrorist Activities and China's Response, Crime Research, 2018(2). 